\title{
Demand Forecast of Emergency Supplies Based on Gray Model
}

\author{
Xi Chen ${ }^{1, \text { a }}$, Zhao Liu ${ }^{2}$ \\ ${ }^{1}$ School of Computer Science, Beijing University of Posts and Telecommunications, Beijing 100876, \\ China \\ ${ }^{2}$ School of Automation, Beijing University of Posts and Telecommunications, Beijing 100876, China \\ a572214342@qq.com
}

Keywords: Gray Model, Demand Forecast, GM $(0,3)$ Model.

\begin{abstract}
This article focuses on the study of the difficult demand forecast of emergency supplies during the emergency relief process. To resolve the limit that there are few parameters available in the emergency relief scene, a gray forecast model with fewer parameters inputted is raised for this issue. To start, the demand forecast of materials is transformed into the predicted deaths, and factors influencing the deaths are analyzed by using the gray degree of association model. The ratio of deaths and local population and mortality are the system characteristic variables of this issue, moreover, rate of housing collapse, GDP, seismic intensity level, Per capita GDP of the affected region, and other parameters are proposed as system related factors variables. Then modeling through gray degree of association, gray relational coefficient and correlation degree are obtained. During the process of forecast, rate of housing collapse and seismic intensity level are regarded as impact factors. Together with the mortality, these three factors make up the GM $(0,3)$ model. There is overwhelming advantage in proving the gray forecast model applied in selecting model reference factors and solving the forecast value. Combining the features of gray-scale theory, a fairly large historical data are no more needed. It is clear that a great improvement has been witnessed compared with other traditional model.
\end{abstract}

\section{Introduction}

The determination of demand is of great importance during the process of emergency relief. According the general logic, the survival population of disaster area and the demand for relief supplies have a positive correlation. In this paper, demand forecast is transformed into the casualties in disaster. There are many factors influencing the casualties after earthquake and other disasters. Taking earthquake for example, the main factor is as follow: house collapse, the size of earthquake, intensity, local population, population density, the time of the earthquake, as well as local economic development, etc. It is always a hard problem of how to estimate the casualties in earthquake ${ }^{[1]}$. In recent years, domestics and overseas scholars have made some researches in this area, and gradually approximation is applied into estimate the casualties to ensure estimated data is relatively close to the actual situation, but at present parameters needed in these methods can hardly be determined after the disaster. Otherwise, forecasting process is a little complicated, and very inconvenient to use ${ }^{[2]}$.

In this paper, a forecasting method with less parameter is proposed, namely gray forecasting model. Firstly, analyze the related factors influencing the casualties. Then, forecast the casualties using the important and easy-got data. Finally, finish the forecast for demand.

\section{Gray Forecasting Model}

Overview of Gray Theory.Gray system refers to the status that both the information known and unknown is exist in the system. Gray System has its own advantages that only a few data are needed when analyzing the system full of uncertainly information. The gray relational analysis is a dynamic method, and a process based on gray system theory. This method measures the relevance degree of study objectives based on the gray correlation degree of different factors, that is same or different degree of developing trends. 
After gray relational analysis have confirmed the relevance degree between different factors, variation trend of forecast target can be forecasted by gray forecast method ${ }^{[3]}$. Gray forecast method is also a method to study the future development of research objectives based on gray theory. Its advantages lies in that less data are needed to analyze the whole system.

\section{Gray Forecasting Model.}

GM $(0, N)$ modeling is based on the accumulation of original series, that is:

$\mathrm{X}^{(1)}=\left\{\mathrm{X}^{(1)}(1), \mathrm{X}^{(1)}(2), \ldots, \mathrm{X}^{(1)}(\mathrm{n})\right\}$

$\mathrm{X}^{(1)}(\mathrm{k})=\sum_{\mathrm{i}=1}^{\mathrm{k}} \mathrm{X}^{(0)}(\mathrm{i}), \mathrm{k}=1,2, \ldots, \mathrm{n}$

$\mathrm{X}^{(0)}(\mathrm{i})$ Is the original data, and $\mathrm{X}^{(1)}(\mathrm{k})$ is the new sequence after accumulation.

If 1-AGO series of $X_{i}^{(0)}(i=1,2, \ldots, m)$ is $X_{i}^{(1)}$, then $G M(0, N)$ model can be stated as:

$\mathrm{X}_{1}^{(1)}(\mathrm{k})=\sum_{\mathrm{i}=2}^{\mathrm{N}} \mathrm{b}_{\mathrm{i}} \mathrm{X}_{\mathrm{i}}^{(\mathrm{i})}(\mathrm{k})+\mathrm{a}$

$b_{i}$ Is the corresponding parameter values of parameter sequence? a stands for a column matrix with each element of 1 .

Least square of parameter column $\hat{b}=\left[b_{2}, b_{3}, \ldots, b_{N}, a\right]^{T}$ is estimated as:

$\widehat{b}=\left(B^{T} B\right)^{-1} B^{T} Y$

In which:

$\mathrm{B}=\left[\begin{array}{cccc}\mathrm{x}_{2}^{(1)}(2) & \cdots & \mathrm{x}_{\mathrm{N}}^{(1)}(2) & 1 \\ \vdots & & & \vdots \\ \mathrm{x}_{2}^{(1)}(\mathrm{n}) & \cdots & \mathrm{x}_{\mathrm{N}}^{(1)}(\mathrm{n}) & 1\end{array}\right]$

$\mathrm{Y}=\left[\begin{array}{c}\mathrm{x}_{1}^{(1)}(2) \\ \mathrm{x}_{1}^{(1)}(3) \\ \vdots \\ \mathrm{x}_{1}^{(1)}(\mathrm{n})\end{array}\right]$

Time response of the model can be obtained ${ }^{[34]}$ :

$\mathrm{X}_{1}^{(1)}(\mathrm{k})=\sum_{\mathrm{i}=2}^{\mathrm{N}} \mathrm{b}_{\mathrm{i}} \mathrm{X}_{\mathrm{i}}^{(1)}(\mathrm{k})+\mathrm{a}, \mathrm{k}=1,2, \ldots, \mathrm{n}$

Regressive restoring formula is:

$\widehat{\mathrm{X}}_{1}^{(0)}(\mathrm{k}+1)=\widehat{\mathrm{X}}_{1}^{(1)}(\mathrm{k}+1)-\widehat{\mathrm{X}}_{\mathrm{i}}^{(1)}(\mathrm{k}), \mathrm{k}=1,2, \ldots, \mathrm{n}-1$

In which:

$\widehat{\mathrm{X}}_{1}^{(0)}(1)=\widehat{\mathrm{X}}_{1}^{(1)}(1)$

\section{Case Analysis}

In this paper, several factors are selected for related analysis, such as house collapse, local population, regional GDP, per capita GDP, intensity, etc.

Data Acquisition.Data in this paper all come from Ministry of Civil Affairs Website, National Bureau of Statistics, Statistical Yearbook of Sichuan Province, National Disaster Reduction Website, etc.

From the data above and data in other website, original data can be listed as Table 3-1:

Table 3-1 Original data

\begin{tabular}{|c|c|c|c|c|c|c|}
\hline Region & $\begin{array}{c}\text { Casualties } \\
\text { (capita) }\end{array}$ & $\begin{array}{c}\text { Rate of } \\
\text { house } \\
\text { collapse }\end{array}$ & $\begin{array}{c}\text { Population } \\
\text { (capita) }\end{array}$ & $\begin{array}{c}\text { GDP(10 } \\
\text { thousand) }\end{array}$ & Intensity & $\begin{array}{c}\text { Per Capita } \\
\text { GDP } \\
\text { (Yuan) }\end{array}$ \\
\hline Mao County & 4016 & 0.7 & 103570 & 101301 & 9.0 & 9512 \\
\hline Beichuan county & 8605 & 0.8 & 160310 & 131631 & 11.0 & 8598 \\
\hline Mianzhu & 11104 & 0.7 & 515830 & 1425244 & 9.0 & 28863 \\
\hline Li County & 103 & 0.2 & 43668 & 63310 & 8.2 & 13245 \\
\hline Pengzhou & 952 & 0.3 & 770749 & 389715 & 7.8 & 14028 \\
\hline Qingchuan County & 4695 & 0.6 & 248000 & 137825 & 9.0 & 6107 \\
\hline An County & 1571 & 0.3 & 484200 & 507278 & 9.0 & 10434 \\
\hline
\end{tabular}




\section{Model Solution.}

1) Data Preprocessing

In order to facilitate calculation, take the ratio of the casualties to the local population as the characteristic variables of the studied system, and house collapse, GDP, intensity, and Per Capita GDP as the related variables of the system ${ }^{[4]}$.

Standardize the data using SPSS, and the results are shown in Table 3-2:

Table 3-2 Standardized data process

\begin{tabular}{|c|c|c|c|c|c|}
\hline Region & $\begin{array}{c}\text { Ratio of } \\
\text { casualties }\end{array}$ & $\begin{array}{c}\text { Rate of } \\
\text { house collapse }\end{array}$ & GDP & Intensity & $\begin{array}{c}\text { Per Capita } \\
\text { GDP }\end{array}$ \\
\hline Mao County & 0.934 & 0.771 & -0.604 & 0.000 & -0.460 \\
\hline Beichuan county & 1.674 & 1.185 & -0.542 & 1.987 & -0.582 \\
\hline Mianzhu & 0.078 & 0.771 & 2.131 & 0.000 & 2.116 \\
\hline Li County & -0.874 & -1.304 & -0.683 & -0.795 & 0.037 \\
\hline Pengzhou & -0.930 & -0.889 & -0.008 & -1.192 & 0.141 \\
\hline Qingchuan County & -0.051 & 0.356 & -0.529 & 0.000 & -0.914 \\
\hline
\end{tabular}

2) Model Result

Gray related coefficients and correlation degree are obtained as Table 3-3 shown:

Table 3-3 Gray related coefficients and correlation degrees

\begin{tabular}{|c|c|c|c|c|}
\hline Region & $\begin{array}{c}\text { Rate of } \\
\text { house collapse }\end{array}$ & GDP & intensity & Per Capita GDP \\
\hline Mao County & 0.905 & 0.438 & 0.567 & 0.463 \\
\hline Beichuan County & 0.723 & 0.350 & 0.811 & 0.345 \\
\hline Mianzhu & 0.642 & 0.367 & 0.970 & 0.369 \\
\hline Li County & 0.750 & 0.886 & 0.968 & 0.573 \\
\hline Pengzhou & 1.000 & 0.570 & 0.841 & 0.532 \\
\hline Qingchuan County & 0.761 & 0.728 & 0.991 & 0.587 \\
\hline An County & 0.985 & 0.533 & 0.597 & 0.721 \\
\hline Correlation degrees & 0.824 & 0.553 & 0.821 & 0.513 \\
\hline
\end{tabular}

As shown in the Table, correlation degrees are ranked as follows:

$r$ rate of house collapse $(0.824)>r$ intensity $(0.821)>r$ GDP(0.553) $>$ r Per Capita(0.513)

Two of these four correlation degrees are less than 0.6, namely regional GDP and Per Capita GDP. These two factors have a fairly low correlation degree with the ratio of casualties, while the ratio of house collapse and intensity have a close relation with the ratio of casualties. Therefore, during the process of gray forecast, the ratio of house collapse and intensity are selected as impact factors ${ }^{[5]}$. Together with casualties (characteristic variables), these three factors build the GM $(0,3)$ model.

Supposing this model as:

Then:

$$
\mathrm{X}_{1}^{(1)}=\mathrm{b}_{2} \mathrm{X}_{2}^{(1)}+\mathrm{b}_{3} \mathrm{X}_{3}^{(1)}+\mathrm{a}
$$

Solution:

$$
\mathrm{B}=\left[\begin{array}{lll}
\mathrm{X}_{2}^{(1)}(2) & \mathrm{X}_{3}^{(1)}(2) & 1 \\
\mathrm{X}_{2}^{(1)}(3) & \mathrm{X}_{3}^{(1)}(3) & 1 \\
\mathrm{X}_{2}^{(1)}(4) & \mathrm{X}_{3}^{(1)}(4) & 1 \\
\mathrm{X}_{2}^{(1)}(5) & \mathrm{X}_{3}^{(1)}(5) & 1 \\
\mathrm{X}_{2}^{(1)}(6) & \mathrm{X}_{3}^{(1)}(6) & 1 \\
\mathrm{X}_{2}^{(1)}(7) & \mathrm{X}_{3}^{(1)}(7) & 1 \\
\mathrm{X}_{2}^{(1)}(8) & \mathrm{X}_{3}^{(1)}(8) & 1
\end{array}\right]=\left[\begin{array}{ccc}
0.7 & 9.0 & 1 \\
0.8 & 11.0 & 1 \\
0.7 & 9.0 & 1 \\
0.2 & 8.2 & 1 \\
0.3 & 7.8 & 1 \\
0.6 & 9.0 & 1 \\
0.3 & 9.0 & 1
\end{array}\right]
$$

$$
Y=\left[\begin{array}{l}
X_{1}^{(1)}(2) \\
X_{1}^{(1)}(3) \\
X_{1}^{(1)}(4) \\
X_{1}^{(1)}(5) \\
X_{1}^{(1)}(6) \\
X_{1}^{(1)}(7) \\
X_{1}^{(1)}(8)
\end{array}\right]=\left[\begin{array}{l}
0.039 \\
0.054 \\
0.022 \\
0.002 \\
0.001 \\
0.019 \\
0.003
\end{array}\right]
$$

Least square of parameter column $\hat{b}=\left[b_{2}, b_{3}, \ldots, a\right]^{T}$ is estimated as:

$$
\widehat{b}=[0.060,0.006,-0.064]
$$


Response time of the $\mathrm{GM}(0,3)$ model is:

$$
\widehat{X}_{1}^{(1)}(\mathrm{k})=0.060 \mathrm{X}_{2}^{(1)}(\mathrm{k})+0.006 \mathrm{X}_{3}^{(1)}(\mathrm{k})-0.064
$$

Further:

$$
\widehat{\mathrm{X}}_{1}^{(0)}=(0.038,0.050,0.026,0.003,0.001,0.020,0.008)
$$

Actual value and predicted value are compared as Table 3-4:

Table 3-4 Comparison between actual value and predicted value

\begin{tabular}{|c|c|c|c|c|c|c|c|}
\hline & $\begin{array}{c}\text { Mao } \\
\text { County }\end{array}$ & $\begin{array}{c}\text { Beichua } \\
\text { n County }\end{array}$ & $\begin{array}{c}\text { Mian } \\
\text { zhu }\end{array}$ & $\begin{array}{c}\text { Li } \\
\text { County }\end{array}$ & $\begin{array}{c}\text { Peng } \\
\text { zhou }\end{array}$ & $\begin{array}{c}\text { Qingchuan } \\
\text { County }\end{array}$ & $\begin{array}{c}\text { An } \\
\text { County }\end{array}$ \\
\hline Actual value & 0.039 & 0.054 & 0.022 & 0.002 & 0.001 & 0.019 & 0.003 \\
\hline Predicted value & 0.038 & 0.050 & 0.026 & 0.003 & 0.001 & 0.020 & 0.008 \\
\hline
\end{tabular}

Result Analysis.According to Table 3-4, Gray forecast model has considerable advantages in selecting reference factors and solving model. From the analysis, predicted value is very close to actual value. Otherwise, reference factors including the rate of house collapse and intensity are easy to get during the actual disaster. Therefore, this model combined with the character of gray theory has great improvement compared with barely the empirical estimation or the linear calculation model. This model can be used as reference and decision basis of actual application to carry out a valuable analysis, with a not large historical data as support.

\section{Materials Demand Forecasting}

Table 4-1 Predicted survivals

\begin{tabular}{|c|c|c|c|c|}
\hline Region & $\begin{array}{c}\text { Population( } \\
\text { Capita) }\end{array}$ & $\begin{array}{c}\text { Rate of } \\
\text { predicted deaths }\end{array}$ & $\begin{array}{c}\text { Predicted } \\
\text { casualties(Capita) }\end{array}$ & $\begin{array}{c}\text { Predicted } \\
\text { survivals(Capita) }\end{array}$ \\
\hline Mao County & 103570 & 0.038 & 3913 & 99657 \\
\hline Beichuan County & 160310 & 0.050 & 7980 & 152330 \\
\hline Mianzhu & 515830 & 0.026 & 13288 & 502542 \\
\hline Li County & 43668 & 0.003 & 128 & 43540 \\
\hline Pengzhou & 770749 & 0.001 & 408 & 770341 \\
\hline Qingchuan County & 248000 & 0.020 & 4898 & 243102 \\
\hline An County & 484200 & 0.008 & 3743 & 480457 \\
\hline
\end{tabular}

Analyzing and modeling the two factors that are house collapse ratio and earthquake intensity, prediction model which is about the number of deaths can be built, and then the number of survival in the stricken area can be calculated in the case of the number of deaths can be predicted. The paper assumes that all of the survivals need salvation. So according to the number of survivals in the stricken area and demand relation of materials, the prediction about the material requirement can be obtained as follow:

Table 4-2 Demanded materials

\begin{tabular}{|c|c|c|c|c|}
\hline Region & $\begin{array}{c}\text { Predicted } \\
\text { survivals(Capita) }\end{array}$ & Tent & Drinking water(bottle) & Food(share) \\
\hline Mao County & 99657 & 8305 & 99657 & 199314 \\
\hline Beichuan County & 152330 & 12694 & 152330 & 304660 \\
\hline Mianzhu & 502542 & 41879 & 502542 & 1005084 \\
\hline Li County & 43540 & 3628 & 43540 & 87080 \\
\hline Pengzhou & 770341 & 64195 & 770341 & 1540681 \\
\hline Qingchuan County & 243102 & 20259 & 243102 & 486204 \\
\hline An County & 480457 & 40038 & 480457 & 960914 \\
\hline
\end{tabular}

And then basing on the material requirement which is obtained by the number of survivals, the paper take the more important three kinds of material for example, they are tank, drinking water, food $^{[6]}$. Counting a tank can accommodate 12 persons, then a person need $1 / 12$ tent, a person needs a bottle of water one day as standard, a person needs two food one day. The material requirement as follow: 


\section{Conclusion}

In order to forecast the demand of materials, firstly, the prediction of materials demanded is transformed into the casualties in disaster area, then, factors influencing the casualties are analyzed with the gray correlation degree model. Finally, two representative parameters are selected to process the gray modeling, and the prediction is accomplished. Result analysis indicates the feasibility of applying gray correlation degree model to forecast the demanded materials.

\section{References}

[1] Development of transport accessibility based on GIS. Journal of Jilin University (Earth Science Edition), Vol 36, pp.182-184, November 2006.

[2] Lee D. Han. Evacuation modeling and operations using dynamic traffic assignment and most assignment and most desirable destination approaches. Transportation Research Board. No.05-2401, 2005.

[3] HE Bin, MENG Qing. Study on Generalization for Gray Forecasting Model [J]. Systems Engineering-theory\& Practice, 2002(9):137-140.

[4] Sinuany-Stern, Zilla, and Eliahu Stern. Simulating the evacuation of a small city: the effects of traffic factors. Socio-Economic Planning Sciences, Vol.27, No.2, 1993, p. 97-108.

[5] Batty, Michael, Jake De Syllas, and Elspeth Duxbury. The discrete dynamics of small-scale spatial events: agent-base models of mobility in carnivals and street parades. Working papers of center for advanced spatial analysis. 2002.

[6] Campos, V.B. G., da Silva, P.A. L., Netto, P.O. B. Evacuation transportation planning: a method of identifying optimal independent routes. In: Surcharov, L.J. (Ed.), Proceedings of Urban Transport V: Urban Transport and the Environment for the 21st Century. WIT Press, Southampton, p.555-564, 2008. 